\title{
Korelasi dan Analisis Lintas Karakter Agronomi Kedelai (Glycine $\max$ [L.] Merrill) Keturunan Persilangan Wilis X MLG 2521
}

\section{Correlation and Path Analysis of Agronomic Characters Soybean (Glycine max [L.] Merrill) Zuriat Wilis Cross With MLG 2521}

\author{
Nyimas Sa'diyah ${ }^{1}$, Christian Raymond Siagian ${ }^{2}$, dan Maimun Barmawi ${ }^{1}$ \\ ${ }^{1}$ Mahasiswa Jurusan Agroteknologi, Fakultas Pertanian, Universitas Lampung \\ ${ }^{2}$ Dosen Jurusan Agroteknologi, Fakultas Pertanian, Universitas Lampung \\ Jl. Prof. Soemantri Brodjonegoro No.1, Bandar Lampung 35145 \\ Email: diosandi24@gmail.com
}

\section{ABSTRACT}

\begin{abstract}
Soybean is one of the crops that produce seeds with high protein content, as well as used by the inhabitants of Indonesia. Domestic soybean production can not meet the needs of the national soybean thus needs to be improved, one through breeding varieties with superior. One important step in plant breeding is the selection. To save time and costs of selection, it is necessary to determine the estimated correlation between characters and to determine the causal relationship between characters used path analysis. Through path analysis can be seen directly and indirectly influence between variables forecaster with the response variable. The purpose of this study to obtain information (1) correlation between characters agronomic towards production. (2) direct and indirect effects of agronomic between characters towards production. The research was conducted from October 2013 until January 2014 in the integrated field laboratory of the Faculty of Agriculture, University of Lampung and observations made in Laboratory of Seed and Plant Breeding, University of Lampung. Soybean seeds used were $F_{5}$ generation zuriat from Wilis x Mlg 2521, Willis and Mlg 2521. The treatment laid out in a randomized block design, 2 replications. The results showed that there was a positive phenotype correlation between character of days to flowering, plant height, number of branches, number of pods, weight of 100 grains with grain weight per plant and there was no correlation between day to harvesting with the seed weight per plant. Direct selection of the most effective was through the number of pods because number of pods have a direct effect almost equivalent to the correlation. The relationship between the number of pods and weight of seeds per plant explained a real relationship.
\end{abstract}

Keywords: correlation, path analysis, selection, soybean,

Diterima: 20 Oktober 2015, disetujui 20 Desember 2015

\section{PENDAHULUAN}

Kedelai merupakan salah satu jenis tanaman palawija dari keluarga Leguminoceae, yang menghasilkan biji dengan kandungan protein yang tinggi, serta banyak dimanfaatkan oleh penduduk Indonesia baik sebagai bahan pangan, campuran pakan ternak, maupun bahan baku industri, terutama minyak dan protein kedelai (Purwono dan Purnamawati, 2007). Berdasarkan data Badan Pusat Statistik pada tahun 2011, produksi kedelai lokal hanya sebesar 851.286 ton atau $29 \%$ dari total 
ketersediaan kedelai pada tahun tersebut. Sementara itu, impor kedelai pada 2011 sebanyak 2.088.615 ton atau $71 \%$ dari total ketersediaan. Oleh karena itu, produksi kedelai nasional perlu di tingkatkan, salah satunya menggunakan varietas unggul yang diperoleh melalui pemuliaan tanaman.

Varietas unggul kedelai memiliki peranan yang penting dalam meningkatkan produksi. Varietas yang digunakan hendaknya harus disesuaikan dengan pola tanam dan musim tanam serta kondisi agroekosistem setempat. Pemilihan varietas juga perlu dikaitkan dengan permintaan konsumen/pasar. Perakitan varietas unggul dapat dilakukan melalui pemuliaan tanaman. Salah satu langkah penting dalam pemuliaan tanaman adalah seleksi. Keberhasilan dan kegagalan program pemuliaan tanaman bergantung pada kemampuan pemulia tanaman untuk memisahkan genotipe-genotipe unggul dengan kegiatan seleksi (Kasno,1992).

Kriteria seleksi adalah suatu identifikasi atau penilaian yang dilakukan pada suatu genotipegenotipe sebagai pendugaan kemampuan genotipe tanaman tersebut. Kriteria seleksi yang umum digunakan adalah berdasarkan karakter hasil atau komponen hasil. Seleksi dapat dilakukan secara langsung maupun tidak langsung. Adanya korelasi antarkarakter menyebabkan seleksi yang diterapkan pada satu karakter akan mengikutsertakan secara simultan karakter-karakter lain yang berkorelasi dengan karakter yang diseleksi (Rachmadi, 2000).

Untuk menghemat waktu dan biaya perlu diketahui korelasi antarsifat. Korelasi berfungsi untuk mengetahui keeratan hubungan antarkarakter. Untuk mengetahui hubungan kausal antarkarakter digunakan analisis lintas. Analisis lintas dapat memisahkan nilai korelasi antara peubah tidak bebas dengan peubah bebas menjadi pengaruh langsung dan tidak langsung.

Penelitian ini bertujuan untuk memperoleh informasi (1) korelasi antarkarakter agronomi terhadap produksi. (2) pengaruh langsung dan tidak langsung antarkarakter agronomi terhadap hasil produksi.

\section{METODE}

Penelitian ini dilaksanakan dari Bulan Oktober 2013 sampai dengan Bulan Januari 2014. Penanaman dilaksanakan di laboratorium lapang terpadu Fakultas Pertanian, Universitas Lampung. Pengamatan dilakukan di Lab. Benih dan Pemuliaan Tanaman Universitas Lampung. Penelitian dilakukan dengan menggunakan RKTS dengan 2 ulangan. Bahan yang digunakan dalam penelitian ini adalah benih kedelai generasi $\mathrm{F}_{5}$ hasil keturunan varietas Wilis x Mlg 2521 oleh Barmawi, Akin dan Sa'diyah, pupuk Urea (50kg/ha), SP36 (100kg/ha), KCl (100kg/ha), pupuk kandang, insektisida Decis berbahan aktif Deltramethrin $25 \mathrm{M} \mathrm{g/l,} \mathrm{dan} \mathrm{Furadan} \mathrm{berbahan} \mathrm{aktif} \mathrm{Karbofuran.}$

Untuk menganalisis korelasi antarkarakter digunakan analisis korelasi dan untuk mengetahui hubungan kausal antarkarakter digunakan analisis lintas. Melalui analisis lintas dapat diketahui pengaruh langsung dan tidak langsung antara peubah peramal dengan peubah respons. Sebelum menghitung koefisien korelasi, terlebih dahulu dilakukan analisis varians dan analisis Kovarians.

Terdapat tiga sumber keragaman yaitu kelompok, genotipe, dan galat. Masing-masing sumber keragaman dihitung derajat bebas, jumlah kuadrat (JK), dan kuadrat nilai tengah (KNT). Kuadrat nilai tengah diperoleh dari JK dibagi dengan derajat bebas . Varians (ragam) lingkungan dan varians (ragam) genotipe di peroleh dari kuadrat nilai tengah. Varians lingkungan diperoleh dari kuadrat nilai tengah galat. Varians genotipe diperoleh dari kuadrat nilai tengah genotipe dikurangi kuadrat nilai tengah galat dibagi kelompok. Varians (ragam) fenotipe diperoleh dari ragam genotipe ditambah ragam lingkungan. 
Pada analisis varians, jumlah kuadrat diperoleh dari data setiap peubah, sedangkan pada analisis kovarians jumlah hasil kali (SP) diperoleh dari perkalian dua peubah. Pada kovarians juga terdapat sumber keragaman. Sumber keragaman terdiri dari derajat bebas, jumlah hasil kali (SP), kuadrat nilai tengah hasil kali (K). Kuadrat nilai tengah hasil kali diperoleh dari SP dibagi dengan derajat bebas . Kovarians lingkungan ( Kov.e) dan kovarians genotipe (Kov. gxy) di peroleh dari kuadrat nilai tengah hasil kali. Kovarians lingkungan diperoleh dari kuadrat nilai tengah hasil kali galat. Kovarians genotipe diperoleh dari kuadrat nilai tengah hasil kali genotipe dikurangi kuadrat nilai tengah hasil kali galat dibagi kelompok. Kovarians fenotipe (Kov. fxy) diperoleh dari kovarians genotipe ditambah kovarians lingkungan.

Korelasi (r) diperoleh dari pembagian kovarians fenotipe dibagi akar ragam fenotipe peubah $\mathrm{x}$ dikalikan dengan ragam fenotipe peubah y. Untuk menguji apakah korelasi itu bermakna, maka dihitung $\mathrm{t}$ hitungnya. $\mathrm{t}$ hitung diperoleh dari korelasi antara peubah $\mathrm{x}$ dengan peubah y dibagi satu dikurangi korelasi kuadrat yang dibagi oleh jumlah pengamatan dikurangi dua. Korelasi dikatakan bermakna (berkorelasi) apabila t hitung lebih besar dari t tabel, pada derajad bebas jumlah pengamatan dikurangi dua.

Koefisien lintas diperoleh dari invers matrik korelasi peubah x dikalikan dengan matrik peubah y.

Karakter agronomi yang diamati pada penelitian ini adalah umur berbunga, umur panen, tinggi tanaman, jumlah cabang, jumlah polong, bobot 100 butir, dan bobot per tanaman.

\section{HASIL DAN PEMBAHASAN}

\section{Korelasi}

Pada penelitian ini variabel utama yang digunakan adalah bobot biji per tanaman. Hal ini disesuaikan dengan tujuan dilakukan penelitian yakni untuk mendapatkan tanaman kedelai yang memiliki bobot biji per tanaman yang berat. Melalui bobot biji per tanaman yang berat, maka kemampuan untuk meningkatkan produktifitas kedelai nasional melalui pemuliaan tanaman semakin tinggi dan peluang untuk melakukan seleksi pada karakter yang diinginkan semakin mudah.

Menurut Ujianto, dkk. (2006), keeratan hubungan suatu karakter dengan karakter lainnya memiliki korelasi yang bermakna positif atau negatif. Apabila suatu karakter memiliki korelasi yang positif berarti bertambahnya suatu karakter akan mengakibatkan pertambahan karakter lainnya. Hal ini juga mengakibatkan apabila karakter yang satu diperbaiki maka karakter lainnya juga ikut mengalami perbaikan. Menurut Adams (1967), karakter yang berkorelasi negatif adalah karakter - karakter yang saling berkompetisi memperoleh persediaan hara dalam proses fisiologisnya. Korelasi negatif dapat terjadi bila salah satu struktur lebih baik daripada struktur lainnya dalam hal penerimaan hara.

Menurut Ujianto, dkk. (2006), dari segi genotipik korelasi dapat terjadi karena adanya faktor linkage dan pleiotropi, sedangkan korelasi fenotipik dapat terjadi karena adanya interaksi antara faktor genetik dan lingkungan. Nilai korelasi antara suatu sifat dengan sifat yang lain dapat digunakan untuk mengetahui keeratan hubungan antarsifat yang diamati. Dalam suatu seleksi, korelasi antarsifat dapat digunakan sebagai dasar apakah suatu sifat dapat digunakan untuk memilih sifat yang lain.

Hasil penelitian yang disajikan pada Tabel 1, menunjukkan hampir seluruh karakter yang diamati seperti umur berbunga, tinggi tanaman, jumlah polong, jumlah cabang, dan bobot 100 butir memiliki korelasi yang positif dan nyata dengan bobot biji per tanaman, sedangkan umur panen tidak berkorelasi dengan bobot biji per tanaman pada $\alpha 0,05$. Hal ini menunjukkan bahwa semakin meningkatnya umur 
berbunga, tinggi tanaman, jumlah polong, jumlah cabang, dan bobot 100 butir akan diikuti dengan peningkatan bobot biji per tanaman. Namun, semakin lama umur panen tidak akan berpengaruh terhadap bobot biji per tanaman. Hal ini disebabkan tidak terdapat korelasi antara karakter umur panen dengan karakter bobot biji per tanaman.

Tabel 1. Koefisien korelasi fenotipe karakter pengamatan

\begin{tabular}{|c|c|c|c|c|c|c|c|}
\hline Karakter & UB & UP & TT & $\mathrm{JC}$ & JP & B100 & BBT \\
\hline UB & & $0,33^{*}$ & $0,25^{*}$ & $0,26^{*}$ & $0,52^{*}$ & $-0,27^{*}$ & $0,32^{*}$ \\
\hline UP & & & $-0,05$ & $-0,14$ & 0,14 & $-0,24 *$ & 0,04 \\
\hline $\mathrm{TT}$ & & & & $0,56^{*}$ & $0,48^{*}$ & $-0,17^{*}$ & $0,48^{*}$ \\
\hline $\mathrm{JC}$ & & & & & $0,30^{*}$ & 0,04 & $0,23^{*}$ \\
\hline JP & & & & & & $-0,06$ & $0,81^{*}$ \\
\hline B100 & & & & & & & $0,29 *$ \\
\hline BBT & & & & & & & \\
\hline
\end{tabular}

Keterangan : $* \quad=$ koefisien korelasi nyata pada $\alpha=0.05$

$\mathrm{UB}=$ Umur berbunga; $\quad$ UP = Umur panen; $\quad$ TT = Tinggi tanaman

JC = Jumlah cabang; $\quad$ JP $=$ Jumlah polong; $\quad$ B $100=$ Bobot 100 butir biji

$\mathrm{BBT}=$ Bobot biji per tanaman.

Umur berbunga memiliki korelasi fenotipe yang positif dan nyata dengan umur panen, tinggi tanaman, jumlah cabang, jumlah polong dan bobot biji per tanaman. Hal ini menunjukkan bahwa makin lama umur berbunga akan menyebabkan ikut meningkatnya umur panen, tinggi tanaman, jumlah cabang, jumlah polong dan bobot biji per tanaman. Keadaan ini dapat terjadi karena apabila umur berbunga lama, maka fase vegetatif tanaman kedelai akan semakin lama sehingga pertumbuhan tinggi tanaman kedelai akan tinggi dan jumlah cabang produktif yang terbentuk akan semakin banyak.

Tanaman kedelai yang memiliki tinggi tanaman yang tinggi dan jumlah cabang produktif yang banyak akan memiliki ruas atau buku - buku dan bunga yang lebih banyak daripada tanaman yang pendek dan bercabang produktif sedikit. Menurut Winarto (2002), meningkatnya tinggi tanaman akan menghasilkan jumlah buku subur per tanaman yang semakin banyak, serta diikuti juga dengan peningkatan jumlah cabang dan daun tanaman sehingga terjadi peningkatan pada proses fotosintesis.

Winarto (2002) menyatakan bahwa jumlah cabang berpengaruh terhadap fotosintat yang dihasilkan. Semakin banyak jumlah cabang produktif yang terdapat pada suatu tanaman akan menyebabkan transportasi fotosintat dari daun ke bagian tanaman lainnya menjadi lebih baik, karena daun - daun yang berada di cabang yang sama akan memberikan hasil fotosintatnya pada polong yang terdapat di cabang tersebut.

Bunga yang banyak berpotensi menghasilkan jumlah polong yang banyak pula dan menyebabkan umur panen yang dalam. Hal ini dimungkinkan karena dibutuhkan asimilat yang banyak untuk mengisi polong - polong tersebut. Menurut Egli et al. (1981), pola akumulasi bahan kering dibagi menjadi 3, yakni (1) periode pertumbuhan eksponensial (berlangsung dalam jangka pendek), (2) periode pertumbuhan linear (laju relatif konstan), dan (3) periode pertumbuhan yang mulai menurun (berlangsung hingga masak fisiologis / saat bobot kering maksimum dicapai).

Menurut Wahdah (1996), periode pengisian biji terjadi selama 54 hari setelah terjadi pembungaan yang terbagi menjadi tiga periode, yakni periode I (0-16 hari), periode II (18 -34 hari) dan periode III (36-54 hari). Proses pengisian polong dapat lebih lama jika tanaman kekurangan air, karena kedelai merupakan salah satu tanaman yang tidak tahan terhadap kekeringan. Menurut Silvius 
et al. (1978) efek dari cekaman kekeringan terhadap pengisian polong adalah berkurangnya fotosintat tersedia yang dibutuhkan dalam proses pengisian polong. Selain hal tersebut, laju akumulasi bahan kering (LABK) pada biji tergantung pada besarnya kemampuan sumber dan besarnya kebutuhan dari wadah biji tersebut. Kemampuan sumber adalah besarnya jumlah asimilat yang dihasilkan oleh organ vegetatif, sedangkan kebutuhan wadah adalah aktivitas metabolik yang terjadi pada biji .(Patterson dan Raper, 1985 dalam Wahdah, 1996).

Tanaman dengan jumlah polong yang banyak akan menghasilkan bobot biji per tanaman yang berat. Hal ini didukung oleh hasil penelitian Wirnas, dkk. ( 2006), Bizeti et al. (2004) dan Iqbal et al. (2003) yang menyatakan bahwa jumlah polong dan jumlah cabang berkorelasi positif dan sangat nyata dengan bobot biji per tanaman.

Umur berbunga berkorelasi negatif dengan bobot 100 butir. Keadaan ini dapat terjadi karena fase vegetatif yang terjadi berlangsung dalam waktu yang cukup lama yang menyebabkan pertumbuhan berlangsung lama dan menghasilkan tanaman yang tinggi, bercabang banyak, serta berpotensi memiliki polong yang banyak. Tanaman yang memiliki jumlah polong banyak akan membutuhkan asimilat dalam jumlah yang besar untuk mengisi polong dalam jumlah yang banyak. Oleh sebab itu, jika asimilat yang dibutuhkan untuk mengisi polong dengan jumlah yang banyak tidak terpenuhi maka akan menyebabkan ukuran polong menjadi kecil dan bobot 100 butir tanaman tersebut akan menjadi ringan. Selain hal tersebut, menurut Gardner et al. (1991) dalam Hartoko (2005), ukuran biji dapat dikendalikan atau dipengaruhi oleh ukuran buah atau polong karena polong kecil menghasilkan biji kecil yang disebabkan keterbatasan dinding polong dan mengakibatkan ukuran sel biji lebih kecil atau lebih sedikit.

Menurut Pandiangan (2012), ukuran biji maksimum ditentukan secara genetis, sedangkan ukuran biji yang diproduksi ditentukan oleh kondisi selama periode pengisian polong. Cekaman cuaca kering selama periode pengisian polong mengakibatkan berkurangnya ukuran biji karena ketersediaan asimilat yang dibutuhkan untuk pengisian polong tidak tercukupi dan akan menghasilkan biji dengan ukuran yang kecil.

Bobot 100 butir memiliki korelasi yang nyata dan positif terhadap bobot biji per tanaman. Hal ini dapat terjadi apabila ukuran biji yang dihasilkan besar menyebabkan bobot 100 butir tersebut akan berat. Ukuran biji yang besar dapat meningkatkan bobot biji per tanaman, sehingga kenaikan bobot 100 butir akan diikuti dengan kenaikan bobot biji per tanaman. Bobot 100 butir tidak disarankan menjadi kriteria seleksi karena karakter bobot 100 butir berkorelasi negatif dengan karakter umur berbunga, umur panen, tinggi tanaman, serta tidak berkorelasi dengan karakter jumlah cabang dan jumlah polong (Tabel 1).

Karakter umur berbunga memiliki korelasi yang positif dan nyata dengan karakter bobot biji per tanaman. Hal ini berarti apabila tanaman terlambat berbunga maka bobot biji per tanamannya akan meningkat. Peristiwa ini dapat terjadi karena jika bunga terlambat berbunga maka fase vegetatif tanaman tersebut berlangsung dalam waktu yang lebih panjang.

Fase vegetatif yang lebih panjang dapat menghasilkan tanaman dengan tinggi tanaman yang tinggi, jumlah cabang produktif lebih banyak, dan ketiak daun sebagai tempat bunga kedelai lebih banyak dari pada tanaman dengan fase vegetatif yang lebih singkat. Apabila asimilat yang tersedia cukup dan dapat di distribusikan secara efektif untuk pengisian polong, maka bobot biji per tanaman akan berat. Sebaliknya, jika asimilat yang tersedia tidak cukup atau hanya mampu digunakan untuk memelihara sel tanaman agar tetap hidup, maka bobot biji per tanaman akan ringan karena kebutuhan asimilat untuk pengisian polong tidak tercukupi. 


\section{Analisis Lintas}

Analisis korelasi tidak dapat mengetahui besarnya sumbangan dari suatu variabel terhadap variabel lain. Untuk melihat hubungan kausal antarsifat karakter agronomi terhadap peubah respons dapat digunakan analisis lintas. Dengan analisis lintas, masing - masing variabel yang dikorelasikan dengan bobot biji per tanaman dapat dibedakan menjadi pengaruh langsung dan pengaruh tidak langsung (Ganefianti, dkk., 2006).

Menurut Singh and Chaudary (1979), terdapat tiga pedoman dasar umum dalam penafsiran koefisien lintas, yakni :

1. Jika koefisien korelasi antara karakter peubah dengan karakter tetap hampir sama besar dengan efek langsungnya, maka koefisien korelasi kedua karakter tersebut benar-benar mengukur derajat keeratan hubungan karakter peubah dengan karakter tetap seutuhnya. Oleh karena itu, seleksi berdasarkan karakter peubah tersebut sangat efektif.

2. Jika koefisien korelasi antara karakter peubah dengan karakter tetap bernilai positif, tetapi efek langsungnya negatif atau dapat diabaikan, maka efek tak langsungnya menjadi penyebab korelasi itu. Dalam keadaan ini semua karakter peubah harus diperhatikan dan diperhitungkan secara serempak.

3. Jika koefisien korelasi antara karakter peubah dengan karakter tetap bernilai negatif tetapi efek langsung bernilai positif dan besar, maka batasilah efek tak langsung yang tidak dikehendaki / yang merugikan sehingga dalam penafsirannya dapat benar-benar memanfaatkan efek langsung tersebut.

Dari data matriks analisis lintas fenotipe yang telah dilakukan (Tabel 2) dapat dilihat bahwa tidak semua variabel yang memiliki korelasi positif dengan bobot biji per tanaman memiliki pengaruh langsung yang positif pula. Hal ini disebabkan pada suatu korelasi selain pengaruh langsung dari suatu karakter, terdapat pula pengaruh tidak langsung melalui karakter lainnya yang menghasilkan koefisien korelasi tersebut. Contohnya pada jumlah cabang, walaupun pengaruh langsungnya bemilai negatif ($0,15)$ jumlah cabang memiliki koefisien korelasi yang positif karena pengaruh tidak langsungnya melalui umur berbunga, umur panen, tinggi tanaman, jumlah polong dan bobot 100 butir memiliki nilai yang lebih besar $(0,38)$ sehingga korelasi jumlah cabang terhadap bobot biji per tanaman tetap positif.

Berdasarkan pedoman Singh and Chaudary (1979), dari enam karakter yang dianalisis terdapat empat karakter yang memenuhi pedoman pertama, yakni umur berbunga, tinggi tanaman, jumlah polong dan bobot 100 butir. Terdapat satu karakter yang memenuhi pedoman kedua, yakni jumlah cabang. Tidak ada karakter yang memenuhi pedoman ketiga. Karakter umur panen tidak memenuhi ke tiga kriteria tersebut, karena umur panen tidak berkorelasi dengan bobot biji per tanaman. Hal ini berarti gen yang mengatur sifat umur panen bersifat independen atau tidak saling berpengaruh dengan gen yang mengatur karakter lain.

Umur berbunga, tinggi tanaman, jumlah polong dan bobot 100 butir memenuhi pedoman pertama karena memiliki koefisien korelasi dengan bobot biji per tanaman yang bernilai positif dan memiliki efek langsung terhadap bobot biji per tanaman yang positif pula, maka koefisien korelasi itu benar-benar mengukur derajat keeratan hubungan variabel umur berbunga, umur panen, tinggi tanaman, jumlah polong dan bobot 100 butir dengan bobot biji per tanaman seutuhnya.

Jumlah cabang memenuhi pedoman kedua karena walaupun koefisien korelasi jumlah cabang dengan bobot biji per tanaman bernilai positif $(0,2336)$, efek langsung jumlah cabang terhadap bobot biji per tanaman bernilai negatif (-0,1509). Menurut Singh and Chaudary (1979), yang menyebabkan adanya korelasi yakni pengaruh tidak langsung melalui komponen atau karakter lain (umur berbunga, 
umur panen, tinggi tanaman, jumlah polong, bobot 100 butir). Dalam keadaan ini semua karakter yang menyebabkan pengaruh tidak langsung perlu diperhatikan dan dipertimbangkan. Oleh sebab itu, perbaikan sifat melalui jumlah cabang akan mengalami kesukaran.

Tabel 2. Matriks Analisis lintas fenotipe berbagai karakter pengamatan dengan bobot biji per tanaman

\begin{tabular}{|c|c|c|c|c|c|c|c|c|c|c|}
\hline \multirow{2}{*}{ Karakter } & \multirow{2}{*}{$\begin{array}{c}\text { Peubah bebas } \\
\text { yang } \\
\text { dibakukan }\end{array}$} & \multirow{2}{*}{$\begin{array}{l}\text { Pengaruh } \\
\text { langsung } \\
\text { (C) }\end{array}$} & \multicolumn{6}{|c|}{ Pengaruh tidak langsung melalui peubah } & \multirow{2}{*}{$\begin{array}{l}\text { Total } \\
\text { pengaruh } \\
\text { tidak } \\
\text { langsung }\end{array}$} & \multirow{2}{*}{$\begin{array}{l}\text { Korelasi ( } r \text { ) } \\
\text { dengan bobot } \\
\text { biji total per } \\
\text { tanaman }\end{array}$} \\
\hline & & & $\mathrm{Z1}$ & $\mathrm{Z2}$ & Z3 & Z4 & $\mathrm{Z5}$ & Z6 & & \\
\hline Umur berbunga & $\mathrm{Z1}$ & 0,0120 & & 0,0079 & 0,0663 & $-0,0399$ & 0,3833 & $-0,1073$ & 0,310285 & 0,3223 \\
\hline Umur panen & $\mathrm{Z2}$ & 0,0243 & 0,0039 & & $-0,0147$ & 0,0214 & 0,1031 & $-0,0964$ & 0,017308 & 0,0416 \\
\hline Tinggi tanaman & $\mathrm{Z3}$ & 0,2693 & 0,0029 & $-0,0013$ & & $-0,0842$ & 0,3566 & $-0,068$ & 0,206004 & 0,4753 \\
\hline Jumlah cabang & Z4 & $-0,1509$ & 0,0032 & $-0,0034$ & 0,1503 & & 0,2192 & 0,0152 & 0,384493 & 0,2336 \\
\hline Jumlah polong & $\mathrm{Z5}$ & 0,7374 & 0,0062 & 0,0034 & 0,1302 & $-0,0449$ & & $-0,0252$ & 0,069747 & 0,8071 \\
\hline Bobot 100 butir & Z6 & 0,3957 & $-0,0033$ & $-0,0059$ & $-0,0463$ & $-0,0058$ & $-0,047$ & & $-0,10831$ & 0,2874 \\
\hline
\end{tabular}

Pzy (galat) = $=\sqrt{1}-(\mathrm{C} 1 \mathrm{r} 1)-(\mathrm{C} 2 \mathrm{r} 2)-(\mathrm{C} 3 \mathrm{r} 3)-(\mathrm{C} 4 \mathrm{r} 4)-(\mathrm{C} 5 \mathrm{r} 5)-(\mathrm{C} 6 \mathrm{r} 6)$ $=0,44$

Dari data analisis lintas fenotipe yang disajikan pada Tabel 2, dapat diketahui bahwa berbeda dengan variabel lainnya, jumlah polong memiliki pengaruh langsung yang hampir setara dengan korelasinya. Menurut Singh dan Chaudhary ( 1979 ), hal ini menunjukan bahwa hubungan antara jumlah polong sebagai faktor penyebab dan bobot biji per tanaman sebagai faktor akibat benar - benar menerangkan tata hubungan yang sesungguhnya. Seleksi langsung terhadap jumlah polong untuk mendapatkan kedelai dengan bobot biji per tanaman yang berat akan efektif karena jumlah polong memiliki pengaruh langsung yang paling besar $(0,7374)$ dibandingkan dengan variabel lain terhadap bobot biji per tanaman dan memiliki korelasi yang besar dengan bobot biji per tanaman $(0,8071)$ sehingga karakter jumlah polong dapat dipilih menjadi kriteria seleksi.

Walaupun umur berbunga, jumlah polong, umur panen dan bobot 100 butir memiliki pengaruh langsung positif dan korelasi positif dengan bobot biji per tanaman, seleksi melalui umur berbunga, jumlah polong, umur panen dan bobot 100 butir tidak cukup efektif karena korelasi dan pengaruh langsungnya tidak cukup besar terhadap bobot biji per tanaman $(<0,5)$ sehingga jumlah polong per tanaman digunakan sebagai kriteria seleksi untuk populasi penelitian ini.

Pengaruh langsung dari faktor sisa (Pzy) terhadap bobot biji per tanaman sebesar 0,44. Menurut Sidwell et al. (1976) besarnya keragaman tidak bebas (bobot biji per tanaman) yang dapat dijelaskan melalui analisis lintas dapat ditentukan sebesar $\left(1-\mathrm{Pzy}^{2}\right)$. Berarti variabel - variabel yang digunakan pada analisis lintas dapat menerangkan keragaman fenotipe bobot biji per tanaman kedelai sebesar $80,64 \%$.

Berdasarkan hasil analisis lintas, karakter yang memiliki pengaruh langsung terhadap bobot biji per tanaman dari yang relatif besar yakni jumlah polong, bobot 100 butir, tinggi tanaman, dan umur panen. Sedangkan karakter yang memiliki pengaruh tidak langsung terhadap bobot biji per tanaman adalah umur berbunga dan jumlah cabang. Hal ini didukung dengan hasil penelitian Wirnas, dkk. (2006) dan Bizeti et al. ( 2004) yang menyatakan jumlah polong, memiliki pengaruh langsung yang besar terhadap bobot biji per tanaman. 
Nyimas Sa'diyah dkk: Korelasi dan Analisis Lintas Karakter Agronomi Kedelai (Glycine max [L.] Merrill) ......

Dari hal tersebut, karakter jumlah polong dapat dijadikan kriteria seleksi yang efektif dikarenakan karakter jumlah polong memiliki nilai korelasi dan koefisien lintas yang besar terhadap bobot biji per tanaman dan paling besar diantara karakter lainnya.

\section{KESIMPULAN}

1) Korelasi fenotipe yang terjadi pada karakter jumlah polong dengan bobot biji per tanaman adalah positif dan nyata serta paling erat jika dibandingkan dengan karakter lainnya. Karakter umur berbunga, tinggi tanaman, jumlah cabang, bobot 100 butir biji berkorelasi dan nyata dengan bobot biji per tanaman. Tidak terdapat korelasi antara umur panen dengan bobot biji per tanaman.

2) Karakter jumlah polong memiliki pengaruh langsung yang paling besar $(0,74)$ terhadap bobot biji pertanaman, sehingga karakter jumlah polong dapat dijadikan sebagai kriteria seleksi yang paling efektif.

\section{DAFTAR PUSTAKA}

Adams, M. W., 1967. Basis of yield compensation in crop plants with special reference to field beans (Phaseolus vulgaris). Crop Science. $7505-510$.

Badan Pusat Statistik, 2011. Laporan Bulanan Data Sosial Ekonomi Januari 2011. Edisi ke-8. Badan Pusat Statistik. Jakarta.

Bizeti, H.S., C. G. P. de Carvalho, J. Souza, and D. Destro. 2004. Path Analysis under multicollinearity in soybean. Brazilian Archives of Biology and Technology Journal. 47(5): 669676.

Egli, D.B., J. E. Leggett., J. Fraser, and C. G. Poneleit. 1981. Control Of Seed Growth In Soya Beans. Ann. Bot. (London) 48:171-176.

Ganefianti, D.W, Yulian, dan A.N. Suprapti. 2006. Korelasi dan sidik lintas antara pertumbuhan, komponen hasil dan hasil dengan gugur buah pada tanaman cabai. Jurnal Akta Agrosia 9(1):1-6.

Hartoko, D. A. 2005. Penampilan Beberapa Mutan kedelai (Glycine max (L.) Merril) di lahan kering pada generasi kedua. Penebar Swadaya. Jakarta.

Iqbal, S., M. Ariq, M. Tahira, M. Ali, M. Anwar, dan M. Sarwar. 2003. Path coefficient analysis in different Genotypes of soybean (Glycine max (L.) Merr). Pakistan Journal of Biological Science. 6 (12): 1085-1087.

Kasno, A. 1992. Pemuliaan Tanaman Kacang-Kacangan. PPTI. Jawa Timur.

Pandiangan, M. B. S. P. K. 2012. Uji Daya Hasil Kedelai (Glycine Max (L.) Merril) Berdaya Hasil Tinggi Di Kampung Sidey Makmur Sp 11 Manokwari. Skripsi. Fakultas Pertanian dan Teknologi Pertanian Universitas Negeri Papua. Papua.

Purwono, L dan Purnamawati. 2007. Budidaya Tanaman Pangan. Penerbit Agromedia. Jakarta. Rachmadi, M. 2000. Pengantar Pemuliaan Tanaman Membiak Vegetatif. Unpad. Bandung. 
Singh RK. and Chaudhary BD. 1979. Biometrical Methods in Quantitative Genetic Analysis. Ludhiana-New Delhi. Kalyani Publishers. 302 p.

Sidwell, R., E. Smith, and R. McNew. 1976. Inheritance and interrelationships of grain yield and selected yield-related traits in a hard red winter wheat cross. Crop Sci. 16:650-654.

Silvius, J. E., D. F. Kramer, and R. E. Lee. 1978. Carbon Assimilation and Translocation in Soybean Leaves at Different Stages of Development. Plant Physiol. 62:54-58.

Ujianto, L. Idris dan T. Mulyaningsih. 2006. Evaluasi potensi plasma nutfah dan penentuan sifat untuk seleksi tidak langsung kacang tanah (Arachis hypogeae L. Merr.) varietas lokal NTB. Agroteksos 15 (4): 259 - 264.

Wahdah, R. 1996. Variabilitas Dan Pewarisan Laju Akumulasi Bahan Kering Pada Biji Kedelai. Skripsi. Fakultas Pertanian Universitas Padjadjaran. Bandung.

Winarto. A. 2002. Peningkatan Produktifitas, Kualitas Dan Efisiensi Sistem Produksi Tanaman Kacang - Kacangan dan Umbi - Umbian Menuju Ketahanan Pangan Dan Agribisnis. Prosiding hasil penelitian. Pusat Penelitian dan Pengembangan Tanaman Pangan, Badan Penelitian dan Pengembangan Pertanian.

Wirnas, D, I. Widodo, Sobir, Trikoesoemaningtyas, dan D. Sopandie. 2006. Pemilihan Karakter Agronomi untuk Menyusun Indeks Seleksi pada 11 Populasi Kedelai Generasi F6. Bul. Agron. (34) (1) 19 - 24 . Departemen Agronomi dan Hortikultura Fakultas Pertanian Institut Pertanian Bogor. Bogor.

Novotny V and Olem H. 1994. Water Quality, Prevention, Identification, and Management of Diffuse Pollution. Van Nostrasns Reinhold. New York

Supono. 2014. Manajemen Kualitas Air Untuk Budidaya Perairan. Universitas Lampung. Bandar Lampung. hal 72.

Wedemeyer, G.A. 1996. Physiology of Fish in Intensive Culture Sistem. Chapman and Hill.

Wurts, A. W. and Durborow, M. R. 1992. Interactions of pH, Carbon Dioxide, Alkalinity and Hardness in Fish Ponds, SRAC Publications. 